\title{
Progesterone mediated changes in the composition of cattle oviduct and uterine fluid
}

\section{Morris $^{1}$, S Hugentobler ${ }^{1,2}$, H Leese $^{3}$, P Humpherson ${ }^{3}$, J Sreenan ${ }^{1}$, M Diskin ${ }^{1}$}

${ }^{1}$ Teagasc, Animal Bioscience Department, Mellows Campus, Athenry, CO. Galway, Ireland, ${ }^{2}$ National University of Ireland, Galway, Ireland, ${ }^{3}$ University of York, York, United Kingdom

Email:dermot.morris@teagasc.ie

Introduction Inadequate systemic concentrations of progesterone in the first few days post insemination are associated with a low probability of embryo survival in cattle One mechanism by which progesterone can affect embryo survival is by altering the composition of oviduct or uterine fluid on which the embryo is dependent for its normal growth and development. The aim of this study was to characterise the effects of changes in the systemic concentration of progesterone on the ionic, amino acid and energy substrate composition of oviduct and uterine fluid in cattle.

Materials and methods All blood sampling, infusion and surgical procedures were carried out under license and in accordance with the European Community Directive, 86-609-EC. Reproductively normal, nulliparous crossbred heifers of similar age (average $20 \pm 4$ months), live weight Exp 1, 413kg $\pm 6.39, \mathrm{n}=11$; Exp. 2, 409kg $\pm 8.51, \mathrm{n}=9$ ) and body condition score (BCS $3.2 \pm 0.1$ units) were used in this study. Oestrus was synchronised by two injections of synthetic prostaglandin (PG; 500 $\mu$ l Cloprostenol, Estrumate ${ }^{\circledR}$, Schering-Plough, Animal Health, Ireland) administered 11 days apart. All heifers were kept indoors and given $4 \mathrm{~kg}$ of concentrates and ad-lib silage. In Experiment 1, beginning on Day 1 of the oestrous cycle, heifers were infused, using a jugular venous catheter attached to a peristaltic pump, with $2.5 \mathrm{ml}$ ethanol $/ \mathrm{hr}$ for $48 \mathrm{hr}$ (Control), or with $0.5 \mathrm{mg}$ progesterone $/ 2.5 \mathrm{ml}$ ethanol $/ \mathrm{hr}$ for the first $24 \mathrm{hr}$ and then with $1.0 \mathrm{mg}$ progesterone $/ 2.5 \mathrm{ml}$ ethanol/hr for the next $24 \mathrm{hr}$ (Supplemented). In Experiment 2, beginning on Day 4 of the oestrous cycle, heifers were infused with $2.5 \mathrm{ml}$ ethanol $/ \mathrm{hr}$ for $48 \mathrm{hr}$ (Control), or with $1.5 \mathrm{mg}$ progesterone $/ 2.5 \mathrm{ml}$ ethanol $/ \mathrm{hr}$ for the first $24 \mathrm{hr}$ and then with $3.0 \mathrm{mg}$ progesterone $/ 2.5 \mathrm{ml}$ ethanol/hr for the next $24 \mathrm{hr}$ (Supplemented). Following infusion, oviduct or uterine fluid was collected over a period of 3 hours using an in-dwelling catheter during midline laparotomy. Plasma progesterone and oestradiol were measured by radioimmunoassay (RIA). The concentrations of eighteen amino acids were measured in oviduct fluid and blood plasma by reversed-phase HPLC (Hugentobler et al., 2007a). Anions and cations were measured by ion chromatography (Hugentobler et al., 2007b). The concentrations of glucose, lactate and pyruvate were measured in oviduct fluid and blood plasma using an autoanalyser (Hugentobler et al., 2008). The concentrations of ions, amino acids and energy sources, in oviduct and uterine fluid and blood were analysed by analysis of variance (PROC GLM, SAS v9.10, Cary, NC). Terms included in the model were treatment (control or supplemented), side (ipsilateral or contralateral to corpus luteum) and side $\mathrm{x}$ treatment. There was no evidence of a side $\mathrm{x}$ treatment interaction or side effect for any ion, amino acid or energy source. Consequently, the data for ipsilateral and contralateral oviducts or uteri were combined and an average value for each animal calculated. A probability of $\mathrm{P}<0.05$ was considered significant.

Results In Experiment 1 systemic progesterone concentration increased over 4 -fold from $0.66 \pm 0.11 \mathrm{ng} / \mathrm{ml}(\mathrm{n}=4)$ to $2.88 \pm 0.39 \mathrm{ng} / \mathrm{ml}(\mathrm{n}=7)(\mathrm{P}<0.001)$ following progesterone supplementation. Systemic oestradiol concentration was not different between control $(0.35 \pm 0.16 \mathrm{ng} / \mathrm{ml})$ and supplemented $(0.38 \pm 0.10 \mathrm{ng} / \mathrm{ml})$ groups $(\mathrm{P}>0.05)$. In Experiment 2, systemic progesterone concentration increased almost 2 -fold from $4.94 \pm 0.44 \mathrm{ng} / \mathrm{ml}(\mathrm{n}=5)$ to $8.19 \pm 1.17 \mathrm{ng} / \mathrm{ml} \quad(\mathrm{n}=4)$ $(\mathrm{P}<0.05)$ following progesterone supplementation. Systemic oestradiol concentration was not different between control $(0.41 \pm 0.15 \mathrm{ng} / \mathrm{ml})$ and supplemented $(0.22 \pm 0.11 \mathrm{ng} / \mathrm{ml})$ groups $(\mathrm{P}>0.05)$.Supplementary progesterone had no effect on the energy substrates in oviduct fluid but increased $(\mathrm{P}<0.05)$ glucose concentration in uterine fluid. Nine of 20 amino acids showed an increase $(\mathrm{P}<0.05)$ in concentration in oviduct fluid following supplementary progesterone, with glycine showing the largest increase of approximately 2 -fold. Progesterone supplementation increased the concentration of valine in uterine fluid. Sulphate concentrations in oviduct fluid decreased $(\mathrm{P}<0.05)$ following supplementary progesterone, however, there was no effect of supplementary progesterone $(\mathrm{P}>0.05)$ on the concentrations of any ion in uterine fluid.

Conclusions The progesterone mediated changes described in the composition of oviduct and uterine fluid may explain, at least in part, the positive relationship between systemic progesterone and embryo growth, development and viability. It is likely that the embryo response to progesterone is the result of changes in the amino acid composition of the oviduct. These data extend our knowledge of the physiological environments of the cattle oviduct and uterus.

Acknowledgements This research was part funded by the Research Stimulus Fund of the Department of Agriculture, Food and Rural Development, Agriculture House, Dublin, Ireland.

\section{References}

Hugentobler, S.A., Morris, D.G., Sreenan, J.M. and Diskin, M.G. 2007. Theriogenology 68, 538-548.

Hugentobler, SA, Diskin, M.G., Leese, HJ, Humpherson, PG, Watson, T, Sreenan, J.M. and Morris, D.G. 2007. Molecular Reproduction and Development 74, 445-454.

Hugentobler, S.A., Humpherson, P.G., Leese, H.J, Sreenan, J.M. and Morris, D.G. 2008. Molecular Reproduction and Development 75, 496-503. 